\title{
THE EFFECT OF HUMIC ACID AND ASCORBIC ACID ON IMMUNIZATION OF CHICKENS AGAINST INFECTIOUS BURSAL DISEASE
}

\author{
EL .Sayed.M.ELSayed.*Asawy.A.M.E **Shalaby .H .A.*** K.A.Deeb**** \\ Animal health Institute \\ *Head of research(pharmacology) **Immunity ***Biochemistry ****Clinical pathology
}

\section{Summary}

This study was conducted on the impact of humic acid and ascorbic acid supplementation on immunization against infectious bursal disease (IBD).Ninety clinically healthy avian broiler chicks(one day old )were divided into three equal groups A,B and C.An attenuated live IBDvirus(IBDV) vaccine was administered at 14 day old in drinking water to all the experimental chicks. Two weeks post-vaccination, chicks of all groups were challenged with very virulent IBDV (field strain).Birds of group B were given humic acid (HA)and group C ascorbic acid (AA) from the beginning till the end of the experiment as feed supplement while group(A) kept as control without any supplement .

Blood and serum samples were collected during scarification on 39 and 49 day for hematological ,biochemical and immunological studies. Gross postmortem finding; bursal indices, average body weights and humeral ELISA antibody response to IBDVwere assessed

Groups (B\&C)showed Leukocytosis, elevated antibodies ,lymphocytic transformation index and phagocytosis percentage beside elevated transaminasis.The uric acid and creatinine were significantly elevated The bursa of fabricius was slightly congested and swollen. The liver was slightly enlarged and dark .

\section{Introduction}

Infectious bursal disease is an acute ,highly contagious disease of young chicks caused by RNA virus belonging to family Birnaviridae (Saif and Lukert ,2003). The virus targets B-Lymphocytes with special reference to highly proliferating IgM bearing cells( Rodenberg et al.,1994 ).It remains the major contributor to economic losses in the poultry industry. The current favored strategy to control IBDV is to vaccinate all chicks against IBDV with live vaccine during the first three weeks of life (Winterfield et al.,1980). An ideal live vaccine should cause neither bursal lesions, nor immunosuppression, stimulate long lasting immunity and protect chicks against classical and variant strains of IBDV. Such vaccine is not available, thus other ways are being investigated to increase protection afforded by IBDV vaccine .The use of humic acid substances (HAS) in feed improve gut health for better nutrient utilization as well as improved the health status by working against pathogens by developing immunity ( Islam et al.,2005; Teravita ,2004;Kocabagli et al.,2002 and Faust 
,1998) .HAS are able to form a protective film on the mucous epithelia of the gastrointestinal tract against infections and toxins (Kuhnert et al.,1991) also help to prevent excessive loss of water via the intestine as well as improving the immune functions ( Humin Tech.,2004).Enhancing IL-1 and IL-3 production ( Haq et al.,2002 \&Corder et al.,2003) .HAS have long been known to exhibit antiviral properties in particular against viruses and viral pathogens ( Thiel et al.,1977;Knoking .,1991;Laub .,2000 and Enviromate.,2002 ).

Ascorbic acid (AA) has been investigated to improve disease resistance to viral disease by increasing IL-2 secration, increasing the number of T-cell (Wu et al., 2000) and enhancing interferon production ( Pardue et al .,1985).

This work was planned to investigate and compare the effect of feed supplementation of (HAS) and ( AA ) on protection against Infectious bursal disease evaluated by using immunological, clinicopathological and biochemical means of investigation .

\section{Chicks:}

\section{Material and Methods}

120 one day Avian broiler chicks were obtained .The chicks possessed maternal IBDV antibodies, housing and rearing procedure and routine management were held under hygienic measures .

\section{Immunostimulant}

Humic acid were obtained commercially and thoroughly mixed with diet at a dose of $2.5 \mathrm{~kg} /$ ton (Kocabagli et al.,2002) as sodium humate granules from (Humin tech.Heerdter .Germany).

Ascorbic acid (vit.C.) was obtained commercially (COOPHAVET-France) and supplemented at $1000 \mathrm{ppm}$ final dietary concentration (Amakye-Amin et al.,2000).

\section{Vaccines :}

Commercial IBDV intermediate vaccine, S706 (MERIAL- France L81192) was used. Each chick received 10 EID50 of the vaccine via drinking water at 14 day of age .

Commercial Lasota (VG /GA strain MERIAL-France) was used for vaccination of chicks against Newcastle disease via drinking water.

\section{Challenge virus:}

Field very virulent IBDV (vvIBDV) was obtained from veterinary vaccine \&sera Institute, Abassia, Egypt .Chicks were challenged with 10 EID50/0.1 ml of the vvIBDV via eye drop instillation (Giambrone and Closser .,1990)

\section{Determination of antibody titere to IBDv :}

Antibody titers to IBDV was assessed using commercially available ELISA kits ( IDEXX, Weestbrook, Marine 0492 USA ). 


\section{Bursal index :}

On $39 \& 49$ days of age, the chicks were weighted, bursae were removed and weighted. The bursal indices were calculated according to (Sharma et al .,1989).

\section{Statistical analysis:}

The obtained data were statistically analyzed according to (Snedecor \&Cochran .,1982).

\section{Experimental design :}

120 one day old Avian broiler chicks (Cairo comp. for poultry) were divided into 3 equal groups (A,B \&C) .The chicks were kept under strict hygienic conditions. The drinking water and ration were supplied ad libitum .Group (A) was kept as control without feed additive ,group (B)feed a ration containing(HA) and group (C) feed with ration containing (AA ) .

All groups were vaccinated against Newcastle disease by (VG/GA strains ) on days $\mathbf{7 , 2 1}$ and $\mathbf{3 1}$ in drinking water .furthermore, the chicks were vaccinated at the age of 14day against IBD with 10 EID50 $/ 0.1 \mathrm{ml}$ of IBDV intermediate vaccine (S706) via drinking water .Two weeks post-vaccination ,all chicks were challenged with vvIBDV containing 10 EID50/0.1 ml via eye drop instillation .

After challenge chicks were observed daily for morbidity and mortality .Half of birds from each group were weighted and scarified on the day 39 and the other half on the day 49 of age for post-mortem examination .Bursas were removed and weighted for calculation of bursal indices .

\section{Sampling :}

On the days of $39 \& 49$ of age samples of whole blood on heparin by cardiac puncture and serum from coagulated blood in plain tube by centrifugation were collected .

A-Immunological studies :Hepranized blood samples were used for lymphocytic transformation according to(Raiel-Balhaa et al.,1985) and phagocytosis assay according to (Woldehiwat andRowan.,1990) .The serum antibody titers were determined using ELISA kits according to (Hoshi et al.,1995).

B-Hematological studies: Hepranized whole blood was used for total leukocytic count according to (Coles ,1986) and blood smears stained with Wright stain for differential leukocytic count according to (Schalm et al.,1975).

C-Biochemical studies : The harvested serum was used for measuring the total protein (Peters.,1968) albumin \& globulins (Drupt.,1972), the activities of alanine aminotransferase (AST) and aspartate aminotransferase (AST) (Reitman andFrankel .,1957), gamma glutamyl transferase (Bernard.,1991) ,creatinine(Seeling and Wust.,1969) and uric acid (Fossat et al .,1980) .

\section{Results and Discussion}

On day39 the leukogram revealed significant lekocytosis due to significant lymphocytosis and non significant heterophilia and monocytosis in group (B), 
while in group (C)there was significant leukocytosis due to significant lymphocytosis ,heterophilia and monocytosis .On day 49 leukocytosis was due to significant lymphocytosis ,heterophilia and monocytosis in group (B), while in group (C) significant leukocytosis was due to significant lymphocytosis and non significant heterophilia and monocytosis (table 1\&2).

Serological response to IBDV vaccine, there was elevation in antibody titers in both group $(B \& C)$ but no significant differences were observed between (HA \&AA) treated groups (table $3 \& 4$ ).

At the end of the experiment, non significant difference in the average body weight was detected between group $(\mathrm{B} \& \mathrm{C})$ but both groups showed high significant mean body weights in comparison to control group (table 5).

Bursal index: The control group (A)showed the lowest bursa index ,but no significant differences were found between treated groups (B \& C) .

In the present study two natural immunstimulant,(HA \&AA)were used . Vaccination was done at 14 days of age after waning of maternal immunity to IBDV , to overcome its adverse effect on vaccination (Van den berg .,2000) . Both (HA \& AA) resulted in increased post-vaccination immunity to IBDV . this was indicated by significant increase of anti-IBDV antibody in both treated groups( B \& C) post-vaccination, in comparison to the control untreated one .Such results confirms the findings that ascorbic acid possess potent immunostimulant activity (McCorkle et al.,1980;Pardue et al.,1985 and Haq $.2002)$.

The significant increase in total leukocytic count, heterophils ,lymphocytes and monocytes in group (B \&C) coincides with the findings obtained by (Perdigon et al .,1998) who suggested that lactic acid producing bacteria could ineract with M-cells which activates payer s patchs lymphocytes that might be liberated from the intestine and reach systemic circulation .

The increased immune response was represented by a significant increase in ELISA titer, lymphocytic transformation index and phagocytosis percentage .Such findings are inagreement with (Nemcova et al.,1999; Perdigon et al 1998 and Simone et al. ,1989 ) who confirmed the immunostimulating effect of probiotics on cell mediated immunity, initiated the induction of lymphokinse and immunoglobulinse, stimulation of non specific host defense mechanism, as well as immunological means of prevention of gastrointestinal infection and increasing the antibacterial activity of lymphocytes in the payer s patches of lymphatic system .

The significant increase in the enzymatic activities of transaminases and glutamyltranspeptidase on both groups $(\mathrm{B} \& \mathrm{C})$ may be due to the effect of the IBDV challenge on liver resulting in alteration of membrane permeability or damage of the hepatic cells leading to escape of these enzymes to the plasma (Coles .,1986 and Peters .,1967) whose stated that the elevated enzymatic activities and changes in the liver and kidneys to IBDV infection are non specific table ( $7 \& 8)$. 
The challenge of chicks with IBDV resulting in an increased level of creatinine and uric acid .The elevation of uric acid and creatinine are expected in birds with impaired renal function (Halliwal.,1981 and Kaneko.,1980) .Such explanation gets along with our finding because the renal congestion interferes with the excretion of uric acid creatinine with consequent increase of their levels in the serum .

It could be concluded that the addition of immunostimulant to the broiler chicks, alleviated the IBDV effect by ameliorating the host defense against infection .

Table (1)Leukogram in chicks scarified on the $39^{\text {th }}$ day :

\begin{tabular}{|c|l|l|l|l|l|}
\hline group & $\begin{array}{l}\text { TLC } \\
10^{3} / \mathrm{ul}\end{array}$ & $\begin{array}{c}\mathrm{H} \\
10^{3} / \mathrm{ul}\end{array}$ & $\begin{array}{c}\mathrm{L} \\
10^{3} / \mathrm{ul}\end{array}$ & $\begin{array}{c}\mathrm{M} \\
10^{3} / \mathrm{ul}\end{array}$ & $\begin{array}{c}\mathrm{E} \\
10^{3} / \mathrm{ul}\end{array}$ \\
\hline $\mathrm{A}$ & $26.38+1.40$ & $7.77+0.39$ & $15.62+0.83$ & $2.11+0.11$ & $0.84+0.04$ \\
\hline $\mathrm{B}$ & $32.63+2.09^{*}$ & $9.11+0.58$ & $19.56+1.25^{*}$ & $2.41+0.15$ & $0.98+0.06$ \\
\hline $\mathrm{C}$ & $32.49+2.27^{*}$ & $9.50+0.68^{*}$ & $19.05+1.35^{*}$ & $2.73+0.02^{*}$ & $0.94+0.05$ \\
\hline
\end{tabular}
* significant $(\mathrm{p}<0.05)$
TLC : total leukocyte
M :monocyte
$\mathrm{H}$ : heterophile
E :eosinophile

Table (2 ):Leukogram in chicks scarified on the $49^{\text {th }}$ day :

\begin{tabular}{|c|c|c|c|c|c|}
\hline group & $\begin{array}{c}\text { TLC. } \\
10^{3} / \mathrm{ul}\end{array}$ & $\begin{array}{c}\mathrm{H} \\
10^{3} / \mathrm{ul}\end{array}$ & $\begin{array}{c}\mathrm{L} \\
10^{3} / \mathrm{ul}\end{array}$ & $\begin{array}{c}\mathrm{M} \\
10^{3} / \mathrm{ul}\end{array}$ & $\begin{array}{c}\mathrm{E} \\
10^{3} / \mathrm{ul}\end{array}$ \\
\hline $\mathrm{A}$ & $28.11+1.49$ & $8.77+0.38$ & $16.52+0.88$ & $1.94+0.08$ & $0.88+0.05$ \\
\hline $\mathrm{B}$ & $35.05+2.24^{*}$ & $10.66+0.68^{*}$ & $20.59+1.32^{*}$ & $2.56+0.16^{*}$ & $1.04+0.07$ \\
\hline $\mathrm{C}$ & $35.76+2.57^{*}$ & $10.18+0.73$ & $21.74+1.57^{*}$ & $2.30+0.17$ & $1.03+0.07$ \\
\hline
\end{tabular}

* significant $(\mathrm{p}<0.05)$ 
Table (3) :ELISA antibody titer, lymphocytic transformation index and phagocytosis percentage in chicken sacrified on the $39^{\text {th }}$ day .

\begin{tabular}{|r|r|c|c|}
\hline Group & ELISA & Lymphocytic transformation index & Phagocytosis \% \\
\hline $\mathrm{A}$ & $1132.80+67.97$ & $1.46+0.12$ & $82.33+1.80$ \\
\hline $\mathrm{B}$ & $1397.60+104.82^{*}$ & $1.66+0.13^{*}$ & $88.11+0.80^{*}$ \\
\hline $\mathrm{C}$ & $1679.00+147.75^{*}$ & $1.58+0.14^{*}$ & $85.11+2.13^{*}$ \\
\hline
\end{tabular}

* significant $(\mathrm{P}<0.05)$

Table (4 ) :ELISA antibody titer ,lymphocytic transformation index and Phagocytosis percentage in chicken sacrified on the $49^{\text {th }}$ day .

\begin{tabular}{|r|r|c|l|}
\hline Group & ELISA & Lymphocytic transformation index & Phagocytosis \% \\
\hline A & $3643.60+200.40$ & $1.38+0.14$ & $80.00+3.00$ \\
\hline B & $4810.70+336.75 *$ & $1.65+0.18^{*}$ & $88.40+1.50^{*}$ \\
\hline C & $4813.40+385.01 *$ & $1.72+0.10 *$ & $90.60+2.11^{*}$ \\
\hline
\end{tabular}

* significant $(\mathrm{P}<0.05)$

Table (5) :The mean bursal indices ( BI )in IBDV vaccinated groups post-challenge .

\begin{tabular}{|c|c|}
\hline Group & Bursal indices \\
\hline $\mathrm{A}$ & $2.5+0.2$ \\
\hline $\mathrm{B}$ & $3.95+0.2 *$ \\
\hline $\mathrm{C}$ & $3.92+0.2 *$ \\
\hline
\end{tabular}

* significant $(\mathrm{P}<0.05)$ 
Table ( 6 ): some biochemical parameters in chicken sacrified on the $39^{\text {th }}$ day .

\begin{tabular}{|c|c|r|r|r|r|r|r|r|}
\hline Group & $\begin{array}{c}\text { ALT } \\
\mu / \mathrm{ml}\end{array}$ & $\begin{array}{c}\text { A ST } \\
\mu / \mathrm{ml}\end{array}$ & \multicolumn{1}{c|}{$\begin{array}{l}\text { GGT } \\
\mu / \mathrm{ml}\end{array}$} & $\begin{array}{r}\text { T.P. } \\
\mathrm{gm} / \mathrm{dl}\end{array}$ & $\begin{array}{r}\text { ALB. } \\
\mathrm{gm} / \mathrm{dl}\end{array}$ & $\begin{array}{r}\text { GLO. } \\
\mathrm{gm} / \mathrm{dl} .\end{array}$ & $\begin{array}{r}\text { Uric acid. } \\
\mathrm{mg} / \mathrm{dl}\end{array}$ & $\begin{array}{r}\text { Creatinine } \\
\mathrm{mg} / \mathrm{dl}\end{array}$ \\
\hline $\mathrm{A}$ & 87.46 & 158.96 & 41.43 & 3.36 & 1.48 & 1.88 & 3.43 & 1.56 \\
& \pm 5.11 & \pm 10.13 & \pm 3.14 & \pm 0.17 & \pm 0.08 & \pm 0.09 & \pm 0.24 & \pm 0.00 \\
\hline $\mathrm{B}$ & $109.22^{*}$ & $191.32 *$ & $52.98^{*}$ & $3.88^{*}$ & 1.32 & $2.56^{*}$ & 4.21 & $1.97^{*}$ \\
& \pm 7.10 & \pm 11.14 & \pm 3.44 & \pm 0.81 & \pm 0.09 & \pm 0.17 & \pm 0.11 & \pm 0.15 \\
\hline $\mathrm{C}$ & 95.13 & 152.13 & 46.11 & 3.42 & 1.45 & 1.97 & 3.45 & 1.68 \\
& \pm 7.13 & \pm 8.11 & \pm 2.98 & \pm 0.22 & \pm 0.11 & \pm 0.13 & \pm 0.28 & \pm 0.12 \\
\hline
\end{tabular}

*Significant $(\mathrm{P}<0.05)$

ALT $=$ Alanine aminotransaminase.$\quad$ AST $=$ Aspartate aminotranspeptidase.

GGT $=$ gamma glut amyl transferase.$\quad$ T.P. $=$ Total protein.

$\mathrm{ALB}=$ Albumin $. \quad \mathrm{GLO}=$ Globulin.

Table ( 7 ):some biochemical parameters in chicken sacrified on the $49^{\text {th }}$ day .

\begin{tabular}{|c|c|c|c|c|c|c|c|c|}
\hline Group & $\begin{array}{c}\text { ALT } \\
\mu / \mathrm{ml}\end{array}$ & $\begin{array}{c}\text { AST } \\
\mu / \mathrm{ml}\end{array}$ & $\begin{array}{l}\text { GGT } \\
\mu / \mathrm{ml}\end{array}$ & $\begin{array}{r}\text { T.P. } \\
\mathrm{gm} / \mathrm{dl}\end{array}$ & $\begin{array}{l}\text { ALB. } \\
\text { gm/dl }\end{array}$ & $\begin{array}{l}\text { GLO. } \\
. \mathrm{gm} / \mathrm{dl} \text {. }\end{array}$ & $\begin{array}{r}\text { Uric } \\
\mathrm{mg} / \mathrm{dl}\end{array}$ & $\begin{array}{r}\text { Creatinin } \\
\mathrm{mg} / \mathrm{dl}\end{array}$ \\
\hline $\mathrm{A}$ & $\begin{array}{l}92.14 \\
\pm 6.11\end{array}$ & $\begin{array}{l}168.17 \\
\pm 11.72\end{array}$ & $\begin{array}{l}44.44 \\
\pm 2.31\end{array}$ & $\begin{array}{r}3.49 \\
\pm 0.31\end{array}$ & $\begin{array}{c}1052 \\
\pm 0.06\end{array}$ & $\begin{array}{r}1.97 \\
\pm 0.06\end{array}$ & $\begin{array}{r}3.33 \\
\pm 0.20\end{array}$ & $\begin{array}{r}1.43 \\
\pm 0.07\end{array}$ \\
\hline B & $\begin{array}{c}94.86 \\
\pm 7.11\end{array}$ & $\begin{array}{l}172.13 \\
\pm 12.91\end{array}$ & $\begin{array}{l}40.86 \\
\pm 3.11\end{array}$ & $\begin{array}{r}3.41 \\
\pm 0.24\end{array}$ & $\begin{array}{r}1.46 \\
\pm 0.10\end{array}$ & $\begin{array}{r}1.95 \\
\pm 0.13\end{array}$ & $\begin{array}{r}3.46 \\
\pm 0.26\end{array}$ & $\begin{array}{l}1.50 \\
\pm 0.11\end{array}$ \\
\hline $\mathrm{C}$ & $\begin{array}{c}118.36^{*} \\
\pm 8.88\end{array}$ & $\begin{array}{c}209.31^{*} \\
\pm 13.61\end{array}$ & $\begin{array}{r}55.12 * \\
\pm 4.13\end{array}$ & $\begin{array}{r}3.62 \\
\pm 0.22\end{array}$ & $\begin{array}{r}1.84 \\
\pm 0.09\end{array}$ & $\begin{array}{l}2.28 * \\
\pm 0.11\end{array}$ & $\begin{array}{l}4.07 * \\
\pm 0.24\end{array}$ & $\begin{array}{l}1.74^{*} \\
\pm 0.10\end{array}$ \\
\hline
\end{tabular}

*Significant $(\mathrm{P}<0.05)$ :

\section{REFERENCES}

-Amakye-Amin ,J.;Lin,T.L.;Hester,P.Y. ;THiagarajan;D.;Watkins,B.A.;and

Wu,C. C. ( 2000) :Ascorbic acid supplemention improved antibody response to infectious bursal disease vaccination in chickens .Poult .Sci, , 79 ) 680 -688.

-Bernard,J.H.( 1991) :Clinical diagnosis and management by laboratory methods

Vol., $18^{\text {th }}$ ed.Sounders Co., pheladelphia .

-Coles ,D.H. (1986 ) :Veterinary clinical pathology.4 $4^{\text {th }}$ Ed.W.B.Sounders

Co.pheladlephia, London, Toronto,Hong Kong.

-Corder, C.;Benghuzzi,H.;Tucci,M.;andCason.Z.(2003) :Delayed apoptosis upon the treatment of Hep-2 cells with ascorbic acid and black seed .Biomed.Sci.Instrum., 
(39)365-370.

-Drupt ,F.(1972) :Dosagede ladlbumine serique pavle de bromocresop.pharma.Biol.vol.9 Tone V1ll ,777.

-Enviromate,T.M.(2000) :Effects of humic acid on animals and humans(literature review and current research ).Effects of humic acid. Enviromate Inc .871 Boat Club Road ,Forth ,Texas 76179 .http:// ww.Enviromate inc.com /effct sha .asp.

-Faust ,R.H.(1998) :What is the formula for humic and fulvic acids? New information!!United Article http ://www.bioag .com /whats-in-humates.html

- Fossat,P.;Prencipe,L.and Berti,C.(1980) :Enzymatic determination of uric acid .clin.26(2) 227-231

-Giambrone,J.J.and closser,J.(1990) :Efficacy of live vaccine against serological serotype of infectious bursal disease virous .Avian Dis .,(37) 7-11.

-Haq,A.;Abdullafif .M.;Lobo ,P.I.;Khabar,K.S.A.;Sheth,K.V.and Al-

Sedairy,S.T.(2002) :Ascorbic acid effect on humin lymphocytes and polymorphonuclear phagocytic activity .Immunopharmacol. (30) 147

-Halliwal,W.H. (1981) :Serum chemistry profiles in health and diseases of birds of prey .In Recent Advances in the study of Rapter disease .Edited by cooper J.E.andGreenwood A.G.Chion ,publication Ltd.,West ,York shire,England

-Hoshi,S.;Nakamura,T;Ninoya,T.and Media,S.(1995) :Induction protective immunity in chicken orally immunized with inactivated IBDV vaccine .Poult. Sci ., 13(3) : 245- 252 .

-Human Tech.,(2004) :Humin feed -Tierfutherzusatz and Veterinar Medizin and Huminsaure Basierende produkte .http://www. Fulvic .de / 045 /animal feed /products / humin feed .html .

-Islam,K.M.S.;Schuhmacher,A.and Gropp,J.M.(2005) :Humic acid substances in animal Agriculture .Pakistan Journal of Nutrition 4(3) :126 -134 .

-Kaneko,J.J.(1980) :Clinical Biochemistry of domestic animals $4^{\text {th }}$ Ed.,Academic Press,Inc .New Yourk, London, Tokyo.

-Knocking ,R.(1991) :Interaction of humic acid and humic acid like polymers with herps simplex virus type 1.Humc substances in the Aquatic and terrestrial Environment Berlin ,pp:408-412.

-Kocabagli ,N.;Alp,M.;Acar,N. and Kahraman,R.(2002) :The effect of dietary huminate supplementation on broiler growth and carcass yield .Poult .Sci.,81:227 -230.

\section{-KÜhnert, V.M.;Bartels,K.P.;Kroll,S.and Lange,L.(1991) :}

Huminsaurehaltige Tierarzneimittel in therapie and prophylaxe bei gastrointestinalen Erkrankungen von Hund und katze Monatshefte Vet .Med .,46: 4-8 .

-Laub ,R. (2000) :Laub developing humate with anti-HIV,HSV,HPV and other antiviral activity .Biotechnology information Institute,Fabruary2000, Antiviral drug and vaccine development information ,,Vol. 12,No. 2 ISBN 9871-9897.

-McCorkle,F.R.;Taylor,R.;Stinson,E. and Glick, B.(1980) :The effect of mega levels of vit.C on the immune response of chickens .Poult .Sci(59)1324-1327. Muscettola,M.;Massai,L.;Tanganelli,C.andGrasso,G (1994 ): Effect of Lactobacilli on interferon production in young and aged mice Ann.N.Y.Acd .Sci.717:226 -232

-Nemcova ,R.;Bomb ,A.,Herich,R.;and Guba,P.(1999) :Study of the effect of lactobacillus paracasifructooligosaccharrides of the faecal microflora in the weaning piglets .Berl. Munch .Tierarztl.Wschr .112: $225-228$. 
-Pardue,S.L.;Thxton,J.P.and Brake,J. (1985): Role of ascorbic acid in chickens exposed to high environmental temperature .J.Appl.Phyiol.(58) 1511 -1516.

-Perdigon ,G.;Veldez,J.C.and Rachid,M.(1998) : Antitumor activity of yoghurt :study of possible immune mechanism.J.Dairy Research.65 (1):129-138 .

- Peters ,G .(1967) : Pathology of gumboro disease .Berl. Munch.Tierarzft. Wochemschr $80: 394-396$.

- Peters,T.(1968) : Colorimeteric method for determination of total serum proteins .Clin .Chem .,14,1147.

- Raiel-Balhaa, G.;Pellerin,J.,L.;Bodin,G.;Abullah,H.H.and Hiron,H. (1985):Lymphocytic transformation assay of sheep peripheral blood lymphocytes .A new rapid assay to read technique.Comp.Immune.Microbial.Infect.Dis.,8 :311 -328 .

-Reitman ,S.and Frankel,S.( 1957 ) :Colormetric determination of transaminases activity .Am .J. Clin .Path.,28:56 .

-Rodenberg,J.;Sharma,J.M.;Belzer,S.W.;Nordgern,R.M.and Naqi.S.(1994):

Flow cytometric analysis of B-cell and T-cell subpopulations in specific pathogen free chickens infected with infectious bursal disease virus .Avian Dis., (38) 16-21 .

-Saif,Y.M.and Lukert,P.D. (2003): Infectious bursal disease in:Disease of poultry ,11 ${ }^{\text {th }}$ Ed.,A.A.A.P.,Lowa state university Press. Ames,Lowa, USA,Pp.649 -663 .

-Schalm,O.W.,Iain ,N.and Carrol,E.I.(1975): Veterinary Hematology $3^{\text {rd }}$ ed.,Lea and Fibiger ,philadelpha, USA.

-Seeling,O.W.and Wust,H.(1969): Colormetric method for determination of creatinine .Arztl.Lab., 15,34 .

-Sharma,J.M.;Dohms,J.E.and Metz ,A.L.(1989) : comparative pathogenesis of serotype 1 isolales of infectious bursal disease virus and their effect on humeral and cellular immune competence specific Pathogen free chicks. Avian Dis. ,(33) 112-124 .

-Simone ,C.de.;Bianchiosalvadori ,B.;Jirillo,E.and Simon ,C. (1989):

Modulation of immune activites in human and animals by dietary lactic acid bacteria

:Nutritional and Properties .201 -213.

-Snedecor ,G.W.and Cochram,W.G. (1982): Statistical methods $8^{\text {th }}$ Ed

.Ames.Lowa state university .

-Teravita ,T.M.(2004): Humates in poultry and stock farming . http:/www. Teravita .Com. Humates/chapter 9 .htm .

-Theil ,K.D.;Kloking,R.;Schweizer ,H.and Sprossing,M. (1977): In vitro studies of the antiviral activity of ammonium humate against herpes simplex virus type 1 and type 2 .Zentrable Bakteriol ., 239:304 -321 .

-Van Den Berg ,T.P (2000):Acute infectious bursal disease in poultry :A review .Avian Pathol, (29) 175 -194 .

-Winterfield ,R.W.;Dhillon A.S.;Thaker H.L. and Alby,L.J.(1980): Immune response of White Leghorn chicks from vaccination with different strains of Infectious Bursal Disease virus .Avian Dis.(24) $178-188$.

-Woldehiwat ,Z. and Rowan ,T. (1990) : Some observation on phagocytosis and killing of staphylococcus aureus by polymorph nuclear leukocytes .Brit . Vet .J .,146:163 .

-Wu,C.C.;Dorairajan,T.and Lin ,T.L.(2000) : Effect of Ascorbic acid supplementation on the immune response of chickens vaccinated and challenged with infectious bursal disease virus.Vet .Immunol.Immunopathol. 74 (2) 145 -152 . 


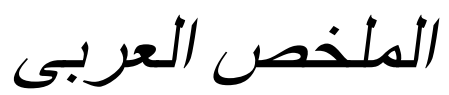

تأثير اضافة حمض الهيومك وحمض الأسكوربيك للعلف على الأستجابة المناعية عند الدائ

تحصين الدو اجن ضد مرض الجامبورو.

ا. ـد/السيد مصطفى السيد ؛ أبو الخيرمحمدابر اهيم عيسوى ؛ حا مد عبد المجيدالأمام شلبى؛ خالدعبدالرحمن الغريب د يب .

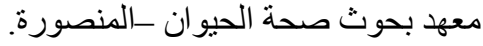

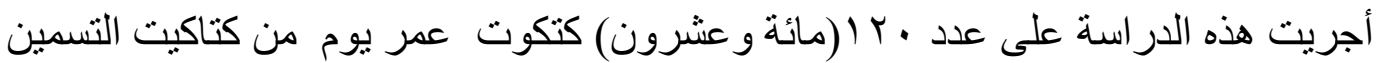

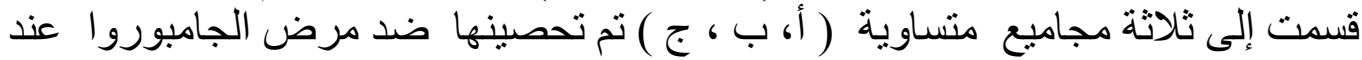

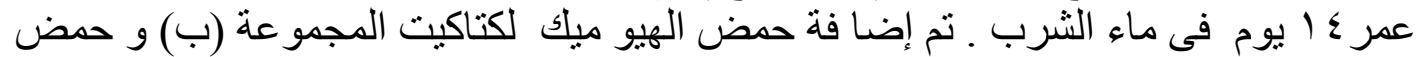

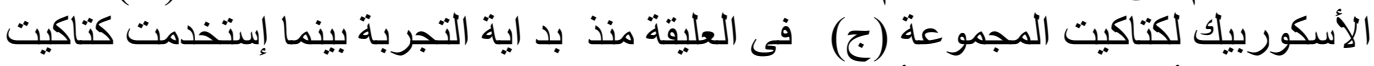

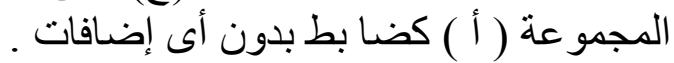

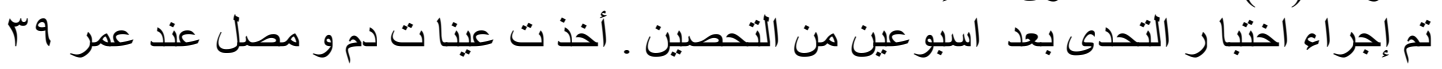

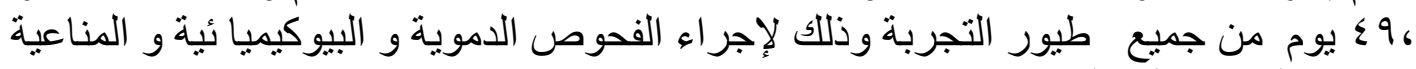

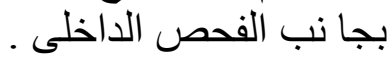
بعد تحليل النتا ئج إحصا ئيا و الفحص وجد أن إستخدام حمض الهيو ميك و الأسكوربيك له تأ ثير

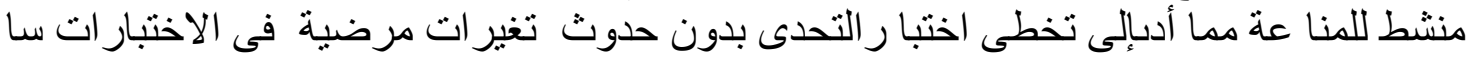

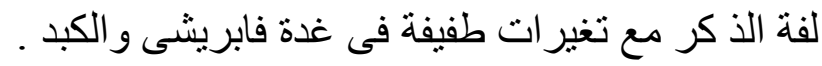

